Rafał Hryszko (D) Uniwersytet Jagielloński rafal.hryszko@uj.edu.pl

\title{
Wkład Alfonsa V Wspaniałomyślnego w upowszechnienie katalońskich zwyczajów kulinarnych w Królestwie Neapolu w XV wieku ${ }^{1}$
}

\begin{abstract}
Abstrakt
W 1442 roku wieloletnie zmagania o tron neapolitański zakończyły się zwycięstwem Alfonsa V Wspaniałomyślnego, władcy Korony Aragonii (1416-1458). Pojawienie się obcego panowania w południowej części Italii pociągnęło za sobą transfer katalońskiej kultury, języka i obyczajów na terenach włoskiego Mezzogiorno. W tym procesie ważne miejsce zajmowały również katalońskie zwyczaje kulinarne, które wykształciły się u schyłku XIV wieku. Jednym z nich była odrębna słodka przekąska zwana z katalońska col·lació (łac. collatio). Organizacja i celebracja tej formy biesiadnej stała się dla katalońskich elit władzy i pieniądza jedną z istotnych form ostentacji zajmowanej pozycji.

W niniejszym artykule autor omówił fragmenty źródeł historycznych, których autorami są m.in. Antonio Beccadelli, Jordi de Centelles, Vespasiano da Bisticci, Giovanni Pontano, jak i posłowie Barcelony i Portugalii oraz inni anonimowi autorzy piszący o czasach wspomnianego władcy.

Dane zawarte w powyższych źródłach wyraźnie wskazują, że Alfons V Wspaniałomyślny wykorzystał znany na ziemiach włoskich zwyczaj słodkiej colazione i co najmniej już w latach 40. XV wieku przydał mu nowego znaczenia. Dzięki

${ }^{1}$ Niniejszy artykuł stanowi rozszerzoną i zmienioną wersję mojej publikacji: The Sweet War, or How Military Campaigns of Alfonso V of Aragon Affected the Eating Habits in Early to Mid-15th Century, ,Perspektywy Kultury”, 26 (3/2019): Biblia w kulturze, s. 135-159.
\end{abstract}


działaniom władcy aragońskiego, a zarazem nowego króla Neapolu słodka przekąska ze słodyczy stała się jednym z instrumentów ostentacji bogactwa i prestiżu nowego władcy południowej części Italii, a wkrótce także innych panów i książąt tego obszaru.

Slowa kluczowe: Królestwo Neapolu, Alfons V Wspaniałomyślny, słodycze, XV wiek

\section{Abstract \\ Contribution of Alfonso V the Magnanimous to the Popularization of Cata- lan Culinary Customs in the Kingdom of Naples in the $15^{\text {th }}$ century}

The wars for Naples ended in 1442 with the victory of Alfonso V the Magnanimous, the ruler of the Crown of Aragon (1416-1458). The emergence of foreign authority in southern Italy entailed the transfer of the Catalan culture, language and customs to the area of Italian Mezzogiorno. In this process, Catalan culinary traditions which developed at the end of the fourteenth century also occupied an important place. One of them was a separate sweet snack, referred to by the Catalan term collació (collatio in Latin). The organization and celebration of collació became an important form of ostentation for the Catalan ruling and financial elites.

In this article, the author discusses excerpts from historical sources whose authors include, among others, Antonio Beccadelli, Jordi de Centelles, Vespasiano da Bisticci, Giovanni Pontano, as well as the ambassadors of Barcelona and Portugal and other anonymous authors writing about the times of Alfonso V the Magnanimous.

The data provided by these sources clearly indicate that this ruler followed the custom of eating sweet colazione known in Italy at this time and gave it a new meaning at least as early as in the 1440s. Thanks to this ruler of Aragon and new Neapolitan king, the sweet snack became one of the instruments of the ostentation of wealth and prestige for the new rulers of the southern part of Italy and soon after also for other princes and lords of the area.

Keywords: Kingdom of Napoles, Alfonso V Magnanimous, sweets, $15^{\text {th }}$ century

Rok 1442 otworzył nowy okres w dziejach Królestwa Neapolu. Oto bowiem po wielu latach zmagań, zapoczątkowanych jeszcze w 1421 roku, na tronie południa Italii zasiadł przedstawiciel kastylijskiej dynastii Trastámara, od 1412 roku władającej Koroną Aragonii, w osobie Alfonsa V Wspaniałomyślnego (1416-1458). Jego kilkunastoletnie rządy oznaczały przekształcenie Neapolu w żywe ognisko renesansu 
promieniujące na cały Półwysep Apeniński. Z drugiej strony zapoczątkowały istotny etap transferu katalońskich zwyczajów, kultury i języka w basenie Morza Śródziemnego. W ten sposób po Balearach, Sycylii czy Sardynii w orbicie oddziaływania kultury katalońskiej znalazły się tereny włoskiego południa.

Zarówno w czasach panowania Alfonsa V, jak i w burzliwym okresie rządów jego następcy Ferdynanda I, zwanego Ferrante (14581494), i jego potomków, na grunt włoski zostały przeniesione katalońskie tradycje kulinarne. Wśród nich niezwykłą rolę zajmowała słodka przekąska zwana z katalońska col·lació (łac. collatio, wł. colazione). Na terenach Korony Aragonii organizacja i celebracja tej formy biesiadnej stały się dla miejscowych elit władzy i pieniądza jedną z istotnych form ostentacji zajmowanej pozycji już u schyłku XIV wieku. Choć sam zwyczaj jedzenia słodyczy w ramach colazione był znany w państwach Półwyspu Apenińskiego co najmniej od XIV stulecia, to dopiero pod wpływem katalońskim w wieku następnym nabrał nowego kształtu i w pełni stał się jednym z elementów włoskiej kultury kulinarnej doby renesansu.

Czym była wspomniana przekąska i jaką rolę odgrywała na obszarach Korony Aragonii w XIV i XV wieku? W jakich okolicznościach i kiedy doszło do jej przeniesienia i upowszechnienia na gruncie włoskim? Jaki był udział Alfonsa V Wspaniałomyślnego jako władcy Korony Aragonii, a następnie też króla Neapolu w upowszechnieniu w tym ostatnim królestwie zwyczajów biesiadnych wyniesionych $\mathrm{z}$ tradycji katalońskiej? - to pytania, które będą wyznaczać kierunek moich rozważań.

\section{Słodycze i zwyczaj słodkiej przekąski w tradycji katalońskiej do czasów Alfonsa V Wspaniałomyślnego}

Przystępując do poszukiwania odpowiedzi na tak sformułowane pytania, w pierwszej kolejności konieczne jest wyjaśnienie kwestii terminologicznych odnoszących się do cukiernictwa katalońskiego. O ile na polskim gruncie na ogół posługujemy się zaledwie jednym 
generalizującym pojęciem ${ }^{2}$, o tyle w językach romańskich, na przykład we włoskim, w odniesieniu do domeny cukiernictwa używa się dwóch bardziej precyzyjnych terminów. Pierwszy z nich - pasticceria - dotyczy sfery piekarnictwa i obejmuje swym zakresem pojęciowym domenę ciastkarstwa. Drugi - confetteria - odnosi się bezpośrednio do wyrobu słodyczy: cukierków, karmelków, powideł, marmolad, mas owocowych na bazie miodu lub cukru, nugatów itp. Ten właśnie zakres pojęciowy będzie płaszczyzną niniejszych rozważań. Czym były i jaką funkcję pełniły wyroby z miodu i cukru na terenach języka katalońskiego u schyłku wieków średnich?

Odpowiedź na tak sformułowane pytanie wbrew pozorom nie jest jednoznaczna. Wynika to z faktu, że wymienione powyżej produkty przez długie wieki były traktowane jako lekarstwa, ich spożycie podlegało zasadom tzw. teorii humoralnej. Ta ostatnia na niwie żywieniowej przypisywała określone cechy każdemu rodzajowi jedzenia, odpowiednio suche, gorące lub też mokre i zimne. Również miód i cukier (upowszechniony od VIII wieku), będące bazowymi składnikami używanymi do wyrobu słodyczy, a zarazem środkami konserwującymi dla różnego rodzaju komponentów dodatkowych (owoców, warzyw, suchych ziaren itp.), były uważane za suche i gorące. Stąd spożywanie zarówno konfitur, owoców kandyzowanych, marcepanów, nugatów, jak i rozmaitych draży z nadzieniem równoważyło negatywne dla zdrowia skutki wynikające z konsumpcji produktów uważanych za zimne i wilgotne, takich jak mięso (Riera-Melis, 2002: 3-43; Hryszko, 2013: 45-48). Nie była to jedyna funkcja, jaką w dobie średniowiecza przypisywano wymienionym powyżej wyrobom. Niejednokrotnie użyte do ich wytwarzania składniki dodatkowe (np. imbir, koper czy inne) sprawiały, że gotowe wyroby były uważane za środki ułatwiające trawienie. W tym wypadku zastosowanie miodu i cukru nie tylko łagodziło ostry smak korzeni, lecz także sprawiało, że tego typu produkty

${ }^{2}$ Zgodnie z definicją zawartą w Encyklopedii PWN cukiernictwo jest definiowane jako ,sztuka wytwarzania słodkich wyrobów spożywczych: cukierków, czekolady, pieczywa cukierniczego trwałego (np. herbatniki, biszkopty) i nietrwałego (np. ciastka, torty)", zob. hasło: cukiernictwo, w: Encyklopedia PWN, [on-line]: http://encyklopedia.pwn.pl/haslo/3888384/ cukiernictwo.html, 20.01.2014. 
były łatwiej przyswajane w procesie konsumpcji (Kuhne-Brabant, 1994: 41; Kuhne-Brabant, 1997: 60; Savage-Smith, 2005: 171; Gajda, 2011: 106-108; Hryszko, 2013: 39-41).

$\mathrm{Z}$ drugiej jednak strony konsumpcja przybierała ponadnormatywne rozmiary, słodkie medykamenty zaczęto bowiem traktować po prostu jako słodycze i przyjmowano je dla przyjemności, podobnie jak robimy to współcześnie. Jak można sądzić, proces ten został zainicjowany na terenach muzułmańskiego Bliskiego Wschodu, prawdopodobnie na przełomie XIII i XIV wieku, a jego echa docierały na obszary Emiratu Grenady, jedynego po 1212 roku państwa muzułmańskiego na obszarach Półwyspu Iberyjskiego ${ }^{3}$.

Pod wpływem kontaktów ze światem Islamu również w późnym średniowieczu w niektórych krajach łacińskiej Europy została zapoczątkowana zmiana w podejściu do słodkich leków. Trudno jednoznacznie wskazać na obszar, gdzie ten proces dokonał się najwcześniej.

W tym kontekście nie bez znaczenia był fakt, że spośród nacji iberyjskich to właśnie mieszkańcy Korony Aragonii, bezpośrednio po kupcach włoskich (głównie Genueńczykach i Wenecjanach), prowadzili intensywną wymianę handlową z Lewantem. Dzięki niej kupcy katalońscy mieli możliwość importu rozmaitych towarów, a wśród nich słodyczy bliskowschodnich ${ }^{4}$.

Kolejnym niezwykle istotnym czynnikiem przyczyniającym się do upowszechnienia słodyczy był fakt, że Korona Aragonii w toku swojego rozwoju objęła także żyzne obszary Walencji i Sycylii. Z tych terenów, dzięki rozwijanym uprawom trzciny cukrowej, pochodził cukier, miejscowe rolnictwo i sadownictwo dostarczały zaś owoce, warzywa i bakalie (Gual Camarena, 1968: passim; Riera-Melis, 2002: 3-43; Coulon, 2004: passim; Marín, 2000: 52-57; Hryszko, 2013: 40-59, 107-120).

3 Szerzej o funkcjonowaniu słodkich wyrobów w świecie Islamu, w tym na terenach muzułmańskiej Hiszpanii w pełnym i późnym średniowieczu, zob. Hryszko, 2013: 48-59.

4 Szerzej o udziale kupców katalońskich w handlu słodyczami z Bliskiego Wschodu, zob. Hryszko, 2013: 107-120. 
Produkcją słodyczy zajmowali się sprzedawcy korzeni - aptekarze (katal. especiers; Suñé Arbussá, Sorní Esteva, 1983: 130-150; Suñé Arbussá, Sorní Esteva, 1985: 71-72; Ferragud Domingo 2005: 436444; Valsalobre 2005: 34-39; Vela i Aulesa, 2006: 839-882; Bénézet, 1999: 62-64; Hryszko, 2013: 121-159). Niektórzy z nich wręcz specjalizowali się w tej sferze działalności. Przykładem takiego especier jest barceloński aptekarz Francesc de Ses Canes, aktywny zawodowo w latach 70. i 80. XIV wieku. W świetle prowadzonych przezeń rachunków wiemy, że nabywcami jego wyrobów byli przedstawiciele ówczesnej elity, wywodzący się w większości z barcelońskiej finansjery kupieckiej. Obok nich nabywcami słodyczy byli dostojnicy kościelni (np. ówczesny kolektor świętopietrza Pere Borell) i świeccy (np. książę Empúries, Jan I, zwany Starszym [1340-1398]). W tym przypadku daje się zauważyć swoisty wzrost zakupów słodyczy przed wybranymi świętami kościelnymi, ale też w okresie postu (Hryszko, 2019: 140-142, 151-152). Czym można tłumaczyć ten fakt?

Chcąc wyjaśnić zaskakujący z pozoru związek między jedzeniem słodyczy a czasem postu, możemy sięgnąć m.in. do pism myślicieli i uczonych katalońskich żyjących na przełomie XIV i XV wieku.

Jednym z nich był dominikanin Wincenty Ferreriusz (Vicent Ferrer, 1350-1419). Obok szeregu działań, których charakterystyka znalazła swoje miejsce w literaturze przedmiotu (Hryszko, Sasor, 2017: 249-266), na uwagę zasługują tematy kazań (spisywanych przez jego słuchaczy) związane z rozmaitymi problemami teologicznymi i wskazaniami natury moralnej. I tak w kazaniu wygłoszonym w katedrze w Walencji w drugą niedzielę Wielkiego Postu, czyli 19 marca 1413 roku, złotousty walencki kaznodzieja skoncentrował się na problemie, jakie potrawy mogły być spożywane w czasie postu.

Z punktu widzenia naszych rozważań niniejsze kazanie ma istotne znaczenie. Oto bowiem w jednym rzędzie $\mathrm{z}$ potrawami postnymi zostały postawione słodycze. Treść przekazu nie pozostawia złudzeń. Słodycze mogą być spożywane w czasie postu (przeł. R. Sasor, w: Hryszko, Sasor, 2017: 277). Przyjęcie takiego stanowiska było pochodną faktu, że słodycze były uważane za lekarstwa. Stąd 
ich przyjmowanie było nie tylko dopuszczalne, ale wręcz nakazane, służyło bowiem wzmocnieniu organizmu w czasie postu.

Niewykluczone, że na opinię walenckiego kaznodziei miał wpływ zwyczaj przekąski postnej (katal. col·lació de dejuni), powszechny już od wieków w kręgach monastycznych. Jego geneza wynikała z faktu, że zgodnie ze wskazaniami zawartymi w regule św. Benedykta (rozdział 41) mnisi w czasie Wielkiego Postu winni byli posilać się jedynie w godzinach wieczornych, zaraz po zakończeniu nieszporów. Te ostatnie miały być odprawione wcześniej, by posiłek mógł być spożyty przez mnichów jeszcze w świetle dnia. Niejednokrotnie ciężka praca i trudne warunki klimatyczne wyczerpujące organizmy mnichów sprawiały, że w trudnym do ustalenia czasie wytworzył się zwyczaj jedzenia lekkiej przekąski w postaci kęsów chleba popijanego wodą lub winem. Zważywszy na fakt, że w trakcie tego posiłku odczytywano fragmenty dzieła Jana Kasjana pt. Collationes patrum (pol. Rozmowy z Ojcami), z czasem zaczęto nazywać go mianem colatio (Carnevale Schianca 2011: 168; Hryszko, 2019: 213-214).

W nieznanym bliżej okresie do wymienionych powyżej składników mnisi zaczęli dodawać inne komponenty, jak na przykład słodycze, których spożycie nie było zabronione przez praktyki postne. Z czasem słodycze zyskały największą popularność. Jak sądzi Carles Vela i Aulesa, w takim właśnie kształcie zwyczaj spożywania słodkiej popołudniowej przekąski postnej o charakterze regeneracyjnym wyszedł poza mury klasztorne i był praktykowany w kręgach świeckich. Słodycze spożywano najczęściej podczas świąt wynikających z kalendarza kościelnego (Vela i Aulesa, 1996: 679; Hryszko, 2019: 213-214).

Około trzeciej ćwierci XIV wieku zwyczaj spożywania słodyczy stał się elementem oficjalnych działań władz publicznych (Vela i Aulesa, 1996: 669-670; Carnevale Schianca, 2011: 168; Claramunt, 1988: 170; Hryszko, 2019: 213-214). Pierwsze wzmianki o col-laciones, w których uczestniczyli przedstawiciele władz miejskich Barcelony, pochodzą z lat 70. XIV wieku. W 1370 roku jeden z rajców zaprosił członków barcelońskiej Rady Stu na poczęstunek, w trakcie którego spożywano wino i słodycze. Podobna sytuacja miała miejsce dwa lata później, kiedy wikariusz królewski (katal. veguer) podjął rajców 
miejskich winem i chlebem z figami (Adroer i Tasis, 1995: 636). Niewykluczone, że uczestnictwo członków Rady Stu w tego typu przyjęciach skłoniło tych ostatnich do wykorzystania lekkiej przekąski jako jednej z form celebracji uroczystości miejskich. O takiej właśnie formie informuje nas Ceremonial dels magnifics consellers $i$ regiment de la ciutat de Barcelona, znany jako Rúbriques de Bruniquer, stanowiący kompilację dokumentów miejskich Barcelony, począwszy od roku 1249, którą sporządził miejski urzędnik Gilabert Bruniquer i Riera (1561-1642)5. Pod rokiem 1376 (brak daty dziennej) odnotowano, że „Senyor en Pere de Luna Cardenal de Aragó vingue â visitar, y veure la Casa de la Ciutat, y fouli dada Collació" (Bruniquer, 1913, 49-50; Vela i Aulesa, 1996: 676; Hryszko, 2013: 218). Podobnej treści zapis pojawił się trzy lata później, również w odniesieniu do wzmiankowanego dostojnika kościelnego: „A 2 de Maig 1379, lo Cardenal de Aragó vingué â visitar los Consellers en Casa la Ciutat, y fouli dada Collació, y costa C s[ou]s (Bruniquer 1913, 49-50; Vela i Aulesa, 1996: 676; Hryszko, 2013: 218).

Także w kolejnych dekadach w Rúbriques de Bruniquer odnotowywano uroczyste col-laciones organizowane przez władze miejskie Barcelony. Tym razem słodyczami i winem byli podejmowani przedstawiciele rodu panującego. Taka sytuacja miała miejsce w 1383 roku, kiedy w Barcelonie przebywał następca tronu, Marcin Młodszy („En la festa de Sinquagesma del any 1383, lo Duc D.n Martí, convidá als Consellers, y als Promens â dinar, y la Ciutat li doná per la messió 75 11[iures] s[ou]s y apres la Duquesa vingué â Casa la Ciutat, donarenli Collació, y costá 22 11[iures] 19 s[ou]s 10": Bruniquer, 1913, 49-50; Vela i Aulesa, 1996: 676; Hryszko, 2013: 218)6.

${ }^{5}$ Szerzej zob.: https://ajuntament.barcelona.cat/rubriques/bruniquer/\#/topic/ rubric.

${ }^{6} \mathrm{O}$ randze i znaczeniu tego elementu ceremoniału dworskiego świadczy fakt, że w oficjalnej kronice najważniejszych wydarzeń z życia miejskiego Barcelony odnotowywano wprawdzie fakt danej wizyty, ale czasem zaznaczano, że gość nie został podjęty słodką przekąską czy napojami. Takie zapiski pochodzą z 1391 roku (,A 21 de Abril 1391, entrá en Barcelona la Senyora Duquesa. A 19 de Juny 1391, entrá en Barcelona el Rey de Armenia, y â 28, vingué â casa de 
Z kolei na podstawie stosownych zapisów w rachunkach miejskich wiemy, że w lipcu 1405 roku władze miejskie Barcelony wydały uroczystą col·lació z okazji wizyty ówczesnego króla Sycylii, Marcina Młodszego. Wówczas na stołach biesiadników znalazła się cała gama łakoci: konfitura z dyni, kandyzowany imbir, złocone cukierki z orzechami piniowymi, cukierki z orzechami pistacjowymi, espongea, a także złocone ptaszki cukrowe wytwarzane w formie (Adroer i Tasis, 1995: 638; Vela i Aulesa, 1996: 675; Hryszko, 2013: 219).

Podobnie rok później, 1 kwietnia 1406 roku, przekąską ze słodyczami został podjęty król Nawarry, Karol. W tym wypadku nie jest znany zestaw serwowanych słodyczy (Bruniquer, 1912: 253, 1913: 51; Vela i Aulesa, 1996: 675; Hryszko, 2013: 219).

Również w późniejszym okresie barcelońska Rada Stu praktykowała i rozwijała zwyczaj podejmowania gości słodką przekąską, niestety ze względu na brak wystarczającej ilości źródeł dynamika i etapy tego procesu nie są nam znane. $Z$ pewnością rozwijał się on i ostatecznie ukształtował najpóźniej w latach 30. XV wieku, w świetle jednej z relacji z początku lat 40 . XV wieku możemy bowiem poznać jego ostateczny kształt. Wspomniany przekaz odnosi się do wydarzeń z 14 stycznia 1440 roku związanych z wizytą w Barcelonie Joana de Clèves, kuzyna Blanki, królowej Nawarry. Biorąc pod uwagę szczegółowy opis zawarty w Rúbriques de Bruniquer, możemy poznać poszczególne elementy ceremoniału słodkiej przekąski. Sprowadzały się one do poniższych punktów:

1. Powitanie orszaku gościa, tj. Joana de Clèves.

2. Rozlokowanie członków jego orszaku w różnych pomieszczeniach siedziby Rady Stu.

3. Uroczyste wniesienie mis ze słodyczami (dla krewnego królowej Nawarry podano słodycze aleksandryjskie).

la Ciutat â veurerla, y no li fou dat â beure, ni Collacio”, „A 28 de Juny 1391: vinguè â Casa de la Ciutat el Rey de Armenia, que era entrat â 20, y no li fou dat â beure, ni Collació.”): https://ajuntament.barcelona.cat/rubriques/bruniquer/\#/ search; hasło: collació. 
Rafał Hryszko

4. Uroczyste wniesienie gigantycznej figury orła barcelońskiego (katal. àguila).

5. Konsumpcja słodyczy zainicjowana przez gościa.

6. Uroczyste wyniesienie wspomnianej figury orła barcelońskiego i powtórne jego wniesienie na czele orszaku służących niosących wino.

7. Powtórzenie powyższego elementu ceremoniału z tą wszakże różnicą, że służący wnieśli słodycze (być może rodzimej proweniencji).

8. Uhonorowanie biesiadników bukietami kwiatów przy dźwięku melodii i w towarzystwie występów kuglarzy.

9. Tańce, w których uczestniczył Joan de Clèves.

10. Odprowadzenie gościa i jego orszaku do wyjścia i jego pożegnanie (tekst kataloński: Comes, 1878: 94-102; Duran i Sampere, Sanabre, 1930: 114-122; Hryszko, Sasor, 2017: 192-215).

Choć szczegółowy opis tego wydarzenia zawarty w oficjalnym ceremoniale miejskim wydaje się nieco emfatyczny, to z przedstawionych punktów można wysunąć następujące wnioski: spożywanie słodyczy w wymiarze ceremonialnej col·lació zyskało sztywną oprawę; serwowaniu słodyczy towarzyszyły elementy urzędowej symboliki miejskiej w postaci wspomnianego orła; gościom, stosownie do ich rangi, dwukrotnie oferowano różne rodzaje słodyczy; ich konsumpcja była związana z piciem wina; elementami towarzyszącymi były uroczysta dekoracja sali, bukiety kwiatów, dźwięk muzyki, popisy kuglarzy, a nade wszystko tańce - te ostatnie zamykały program oficjalnej wizyty.

Te i inne przykłady wyraźnie dowodzą, że w okresie od lat 70. XIV wieku do schyłku lat 30. następnego stulecia w Barcelonie w pełni wykształcił się zwyczaj spożywania słodyczy w ramach lekkiej przekąski zwanej col·lació. W miarę upływu czasu zyskała ona na randze i znaczeniu i wpisała się w poczet ceremonialnych działań tamtejszej rady miejskiej związanych z honorowaniem oficjalnych gości przybywających do Barcelony. Co więcej, ilość, jakość i różnorodność serwowanych słodyczy w przestrzeni publicznej stały się 
ważnym instrumentem polityki propagandowej barcelońskiej Rady Stu, stanowiącej reprezentację bogatego patrycjatu stolicy Katalonii .

Dotychczasowy stan badań nie pozwala jednoznacznie stwierdzić, kiedy i w jakiej formie uroczyste przekąski ze słodyczami dotarły na dwór władców Korony Aragonii. Jedno jest pewne: jak zaświadczają źródła, już ostatni przedstawiciele rodzimej katalońskiej dynastii (Piotr IV Ceremonialny, Jan I Myśliwy czy Marcin I Ludzki) darzyli słodycze dużą estymą i wprowadzili je nawet do oficjalnych obrzędów, czego przykładem może być ceremoniał koronacyjny Piotra IV Ceremonialnego (1336-1387), gdzie zaznaczono, że podczas długiej uroczystości kościelnej koronowana para królewska winna posilać się słodyczami (Maranges, 1998: 29; González Hurtebiese, 1907: 169, 172, 174; Girona i Llagostera, 1913-1914: 553). Z kolei inni władcy spożywali słodycze wystawione w komnatach królewskich, o czym informują nas stosowne źródła (González Hurtebiese, 1907: 148188; Girona i Llagostera, 1913-1914: 553). Niestety brak wzmianek o tym, czy we wspomnianych uroczystych przekąskach uczestniczyli poprzednicy Alfonsa V Wspaniałomyślnego i on sam w pierwszych latach swojego panowania.

\section{Słodycze i zwyczaj słodkiej przekąski na ziemiach włoskich do czasów Alfonsa V Wspaniałomyślnego}

Jak można sądzić, produkcja i spożywanie słodkich medykamentów na terenach włoskich miały jeszcze starszą tradycję niż na obszarach katalońskich. Wynikało to z szeregu czynników. Wśród nich istotną rolę odgrywało zaangażowanie kupców włoskich w handel dalekosiężny, w którym cukier uchodził za jeden z istotnych towarów. Kupcy włoscy, głównie Wenecjanie i Genueńczycy, sprowadzali go z Bliskiego Wschodu, Cypru, a w XV wieku z Granady, Madery i Wysp Kanaryjskich (Plouvier, 1999: 201; Kuhne-Barabant, 1997: 60; Ouerfelli, 2008: 541-542). Osobne miejsce zajmowała dostępność

${ }^{7}$ Szerzej ten temat został omówiony w pracy: R. Hryszko, op. cit., s. 214-216. 
poszczególnych składników w postaci owoców i warzyw lub ,produktów leśnych", pochodzących z miejscowego zaplecza surowcowego.

Również w odniesieniu do państw włoskich trudno jednoznacznie wskazać, kiedy słodkie wyroby tamtejszych aptekarzy - speziari zaczęto uznawać za słodycze. Wydaje się, że proces ten dokonał się co najmniej w XIII wieku i mógł być bezpośrednio związany ze wzrostem spożycia cukru i coraz większym zapotrzebowaniem na produkty wytwarzane na jego bazie. O takim właśnie zjawisku pisał mediolański medyk Maino de Maineri (1290/1295-1365/1368), znany także jako Maginus Mediolanensis, w swoim dziele pt. Liber regiminis sanitatis, które powstało w Paryżu w latach 1331-1334. ${ }^{8}$ W rozdziale 26 (w trzeciej części swojej pracy), zatytułowanym De confectionibus et earum usu, czytamy:

Quia homines sani communiter utuntur confectionibus et ante cibum et post, et stomacho pleno et vacuo, et tempore calido et frigido, bonum michi videtur de confectionibus hic facere unum capitulum speciale. Scienum igitur quod homines communiter utuntur in sanitate forum confectionibus magis ad voluntatem quam propter necessitatem [podkreślenie moje - RH] (Regimen, 1506: XLVIII).

Słowa włoskiego medyka nie pozostawiają złudzeń. Jego zdaniem słodkie lekarstwa były jedzone nie z potrzeby terapeutycznej, warunkowanej zaleceniami teorii humoralnej, lecz po prostu z czystego łakomstwa. Z drugiej strony spostrzeżenie Maino de Maineriego może stanowić dobitne potwierdzenie zmiany podejścia do słodkich leków, które już wtedy były traktowane jako słodycze - confetti.

Jak można sądzić, podobne zjawisko miało miejsce w odniesieniu do sposobów ich spożycia. Wydaje się, że przybrały one formę pewnego rytuału, praktykowanego w określonym czasie i warunkach.

Pierwotnie konsumpcja słodyczy stanowiła część posiłku. Słodycze jedzono przed daniami głównymi lub/i bezpośrednio po ich konsumpcji, co zgodnie z zasadami teorii humoralnej miało zapewnić

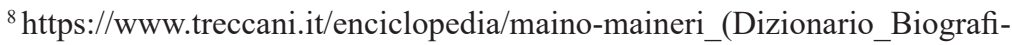
co), 10.11.2019.
} 
równowagę humoralną organizmu. O takich formach i okolicznościach spożywania słodyczy na terenach włoskich informują nas XIV-wieczne źródła historyczne, w których zamieszczono opisy uroczystych przyjęć związanych z celebrowaniem ważnych wydarzeń w życiu jednostki bądź danej wspólnoty. Do takich właśnie należały uczty z okazji pasowania na rycerza Francesca Bandinellego, które miały miejsce w Sienie w 1326 roku. Jak zaznaczono w źródle, w trakcie przyjęć serwowano confecti di nançi e di rieto (Benporat, 2001: 35, 126; Benporat, 2005: 73; Hryszko, 2013: 242). W podobnym kontekście słodycze i wino pojawiały się podczas analogicznej uroczystości, która miała miejsce we Florencji w 1388 roku na cześć Giovanniego Panciatichi (Benporat, 2001: 136; Benporat, 2005: 73; Hryszko, 2013: 242-243). Jak można sądzić, w obu wypadkach konsumpcja słodyczy mogła mieć tradycyjne uzasadnienie wynikające z zasad teorii humoralnej, choć z drugiej strony z pewnością była podyktowana opisanymi powyżej względami.

Z czasem spożycie słodyczy łączono $\mathrm{z}$ winem i w takim kształcie konsumpcja obu produktów stopniowo oddzielała się od pozostałych elementów uczty, stając się autonomiczną przekąską, choć pierwotnie nieobdarzoną własną nazwą. Dla przykładu, bohaterowie poszczególnych nowel Dekameronu Giovanniego Boccaccia wielokrotnie posilający się winem i słodyczami na ogół czynili to w ramach rozrywki i wypełnienia czasu wolnego (Boccaccio, 1975: 30, 45, 48, 88, 171, 227).

Z kolei wzmianki źródłowe odnoszące się do spożywania słodyczy na gruncie florenckim w pierwszych dekadach XV wieku zdają się wskazywać, że słodkim produktom tamtejszych speziari zaczęto nadawać nowe znaczenie. Obok dotychczasowej roli związanej z konsumpcją na płaszczyźnie prywatnej, słodycze weszły do przestrzeni publicznej jako jeden z elementów świętowania uroczystości. W tym właśnie kontekście słodycze najwcześniej pojawiły się zarówno z przeznaczeniem do bezpośredniej konsumpcji, jak i w charakterze podarunków, które miejscowe władze wręczały prominentnym osobom przybywającym do stolicy Toskanii. Świadczą o tym różne rodzaje słodkości (pinocchiati rossi, bianchi, dorati, 12 torte di marzapane in su dui assi 
d'abeto), jakie ofiarowano papieżowi Marcinowi V (1417-1431) podczas jego wizyty we Florencji w 1418 roku (Benporat, 2007: 48-49). Wzmianki o słodyczach w takiej roli znajdujemy też w dzienniku, którego autorem jest Bartolomeo del Corazza. I tak 19 czerwca 1429 roku 16 scatole di confetti, tregea, pinocchiati e zuchata, 4 torte di marzapane ofiarowano przybyłemu do Florencji księciu Salerno, Antonio Colonnie, który był krewnym ówczesnego papieża Marcina V (Corazza, 1894: 281). Natomiast w odniesieniu do wydarzeń z 1434 roku, Corazza odnotował, że słodyczami i innymi produktami konsumpcyjnymi byli podejmowani poszczególni kardynałowie przybywający do Florencji (Corazza, 1894: 288). Jak można sądzić, w tym ostatnim wypadku słodycze zostały bezpośrednio skonsumowane w ramach przyjęcia.

Świadectwa źródłowe z kręgu florenckiego pozwalają nam uchwycić jeszcze jedną rolę słodyczy. Otóż w nieznanym bliżej okresie, na przełomie XIV i XV wieku lub w pierwszych dwóch dekadach XV stulecia, spożywanie słodyczy zaczęto wiązać z balami i turniejami. Jedna z najwcześniejszych wzmianek źródłowych dotyczących tego zagadnienia pochodzi z 2 lutego 1420 roku. W tym bowiem dniu słodycze pojawiły się podczas rozrywek organizowanych przez władze Florencji dla mieszkańców miasta, tj. podczas balów czy turniejów, które odbywały się w czasie karnawału na piazza dei Signori. Jak czytamy w diariuszu Bartolomea del Corazzy:

E per molto ballare deierono due volte con confetti: venivano giovani 22 con 22 confettiere piene di triggiea e pionocchiati, e con nobli vini, e poi l'ultima volta, cioè la terza volta, con zuccherini. Poi, dato l'onore, fecino giostre in sulla detta piazza... (Corazza, 1894: 276).

Podobny rodzaj rozrywki władze florenckie zapewniły mieszkańcom miasta już kilkanaście dni później, tj. 26 lutego 1420 roku. W tym wypadku cytowany powyżej Bartolomeo del Corazza nie odnotował poczęstunku ze słodyczami, co jednak nie wyklucza możliwości ich serowania (Corazza, 1894: 276).

Opisany zwyczaj publicznego świętowania kultywowano również w późniejszych latach. Władze florenckie wydawały bowiem uroczyste 
bale, podczas których serwowano słodycze, również z okazji wizyt prominentnych gości. Jak podaje w swoim dzienniku Francesco di Tommaso Giovane, w październiku 1435 roku z okazji wizyty we Florencji słynnego wówczas kondotiera Francesca Sforzy na florenckim Piazza dei Signori zaplanowano organizację balu i w związku z tym władze florenckie poczyniły spore zakupy słodyczy. Jak zanotował wspomniany autor: „Pagano loro alle spese del Commune per lo stecato fior. 10, e libbre 245 di pinochiati orientali e dori e fiaschi 90 di trebbiano e tutte spese di portalovi e altre cose necessarie" (Corazza, 1894: 290, przyp. 3). Niestety padający deszcz skutecznie uniemożliwił organizację przedsięwzięcia w przewidzianym terminie (13 października 1435 roku), a Bartolomeo del Corazza nie zanotował, czy i kiedy skonsumowano słodycze zakupione na tę uroczystość (Corazza, 1894: 286).

Warto podkreślić, że zwyczaj spożywania słodyczy w trakcie balów i turniejów w stolicy Toskanii był kontynuowany również w późniejszym czasie. Szczegółowych informacji dostarcza nam anonimowy poemat pt. Terze rime in lode di Cosimo de' Medici e de'figliuoli e dell'onoranza fatta l'anno 1459 al figliuolo del duca di Milano e al Papa nella loro venuta a Firenze (Newbigin, 1459: 92, 101-103). Na podkreślenie zasługuje fakt, że anonimowy autor tego poematu, opisując przebieg balu i turnieju, wyraźnie zaznacza, że przerywnikiem w rozrywce była konsumpcja słodyczy w ramach colazione. Ponadto na uwagę zasługuje ceremonialne wniesienie słodyczy. W poemacie zostało ono przedstawione w następujący sposób:

E, conclusive, ballossi un'altr'ora ed ordinossi un'altra collazione come la prima: e fu più magna ancora!

perch'ebbe l'usat'ordine e ragione, ma, doppo le quaranta confettiere pien' della nominata confezzione, quattro gran' zane si potêr vedere dorate e portate alto da scudieri, colme di pinnocchiati, al mio parere. (Newbigin, 2011: 103) 
W 1433 roku w okolicach Florencji znalazł się orszak Zygmunta Luksemburskiego, który zmierzał na koronację cesarską do Rzymu. Jak zaznacza Vespasiano da Bisticci, przyszły cesarz skierował swoich posłów do miasta nad Arno. Wysłannicy cesarscy zostali przyjęci z wielką pompą, a z okazji ich przybycia urządzono publiczny bal, w którym wzięła udział miejscowa młodzież. Elementem świętowania stała się una bellissima collazione, która nastąpiła bezpośrednio po tańcach „Ballato per lungo spazio, fu ordinata una bellissima collezione, e fuori dell'ordine di portare le collezioni in simili feste" (Vespasiano da Bisticci, 1859: 541-542) ${ }^{9}$.

Przytoczone powyżej przykłady, choć odnoszące się jedynie do kręgu florenckiego, pozwalają stwierdzić, że na obszarach państw włoskich w XIV wieku i pierwszych dekadach następnego stulecia stopniowo urozmaicano formy spożywania słodyczy. Z drugiej strony konsumpcja słodyczy została ściśle powiązana z podniosłymi chwilami w życiu jednostek i zbiorowości. Nabyła również nimbu wyjątkowości i stała się instrumentem, za pomocą którego można było podkreślić uroczysty czy ludyczny charakter danego wydarzenia. W tym miejscu godny odnotowania jest fakt, że w przytoczonych powyżej źródłach dotyczących wydarzeń sprzed 1442 roku użycie terminu colazione w odniesieniu do słodkiej przekąski jest stosunkowo rzadkie. Czy może to stanowić przesłankę do tezy, że dopiero przejęcie tronu neapolitańskiego przez Alfonsa V Wspaniałomyślnego stało się istotnym asumptem do upowszechnienia zwyczaju colazione i to w skrajnie ostentacyjnej i ceremonialnej formie? Chcąc odpowiedzieć na tak sformułowany problem badawczy, konieczna jest uważna analiza źródeł opisowych odnoszących się do tego zagadnienia.

${ }^{9}$ Interesujący nas przekaz Vespasiana da Bisticci dotyczy Alessandry de Bardi. To właśnie ta przedstawicielka możnego rodu florenckiego zajmowała się serwowaniem mis pełnych słodyczy, co, jak zaznaczył autor, stanowiło dość osobliwą sytuację: ,per la sua destrezza fu ordinato che la Alessandra [de’ Bardi] pigliassi in mano una confettiera piena di confetti, e portassegli lei agli ambasciadori, con una tovagliuola di Rensa in sulla spalla" (Vespasiano da Bisticci, 1859: 543). 


\section{Słodycze i zwyczaj słodkiej przekąski w kręgu Alfonsa V Wspaniałomyślnego po zdobyciu Neapolu w 1442 roku}

Z pewnością z opisanym powyżej ceremoniałem miejskim Barcelony musiał się zetknąć Alfons V Wspaniałomyślny. Nie wiemy, czy on sam brał udział w uroczystych col-lacions jeszcze przed zaangażowaniem się w sprawy włoskie, choć wydaje się to całkiem prawdopodobne. Na korzyść tej hipotezy przemawia fakt, że na potrzeby konsumpcyjne władcy w kolejnych latach były zamawiane różnego rodzaju słodycze (problem ten został omówiony w odrębnym miejscu, zob. Hryszko, 2019: 141). Z pewnością aragoński monarcha nie ignorował ich roli, a nade wszystko potencjalnego wydźwięku propagandowego, jaki towarzyszył słodyczom. Dobitnym tego przykładem jest fakt, że 26 lutego 1443 roku w pierwszą rocznicę zdobycia Neapolu, podczas uroczystego pochodu orszaku triumfalnego, upamiętnionego po latach na łuku triumfalnym wkomponowanym w jedną z bram Castel Nuovo, słodycze były niesione w misach przez 400 młodzieńców. Opis tego wydarzenia zamieścił anonimowy autor w swojej relacji pt. Come lo Re Alfonso d'Aragona entrò alla città di Napoli col carro trionfale, gdzie po przedstawieniu orszaku triumfalnego, w którym uczestniczył sam król Neapolu, czytamy:

Poi seguita la vittoriosa e felice entrata, passato lo primo e principale Arco triomfale del Mercato, dove sta, e allora stava, la scaturiente fontana di aqua limpida e chiara: ivi all'entrare furo[no] circa $\mathbf{4 0 0}$ giovani con gran numero di piatti d [i] diversi confetti [moje podkreślenie - RH], con calze e giupponi colla divisa di casa d'Aragona, con una calza di color verde, la manca, e l'altra calza dritt[a] mezza bianca mezza rossa (Anonim, 1908a: 479-480).

Powyższy opis wydaje się jednoznacznie wskazywać na fakt, że w wymiarze instrumentów propagandowych słodycze zajęły niezwykle wysoką pozycję. Jak można sądzić, nie wystarczała tu sama ilość, nowy władca Królestwa Neapolu nadał konsumpcji słodkości nowy wymiar. Szczególnie przydatna w tym kontekście była słodka przekąska, czyli col·lació. 
Chronologicznie najwcześniejsze informacje odnoszące się do interesującego nas zagadnienia pochodzą z 1443 roku i zostały zawarte w relacji jednego z przedstawicieli władz miejskich Barcelony przebywających w otoczeniu Alfonsa V Wspaniałomyślnego.

W liście z 4 kwietnia 1443 roku skierowanym do barcelońskiej Rady Stu poseł Antoni Vinyes opisał okoliczności pertraktacji dyplomatycznych dotyczących planowanego małżeństwa władcy Ferrary, Leonella d'Este (1407-1450) z jedną z córek władcy Neapolu. Choć sam przekaz był stosunkowo lakoniczny, to poseł barceloński odnotował, że po zawarciu porozumienia pod wieczór została wydana uroczysta przekąska ze słodyczami (,E fetes les cartes se féu aqui gran collació”, Madurell Marimón, 1963: 227, n. 169).

Kontekst dyplomatyczny nie jest jedyną płaszczyzną, w której pojawia się termin col·lació. Osobne miejsce zajmował grunt rodzinny samego władcy. Oto bowiem ze wzmianki innego posła barcelońskiego dowiadujemy się, że tego typu przyjęcie zostało zorganizowane 2 sierpnia 1450 roku na Zamku Kapuańskim (Castel Capuano) w Neapolu z okazji chrztu wnuczki Alfonsa, Eleonory, która była córką nieślubnego syna monarchy, Ferdynanda, zwanego Ferrante. Jak czytamy w relacji wspomnianego posła, bezpośrednio po ceremonii kościelnej jej uczestnicy zgromadzili się w wielkiej sali tamtejszego zamku. Pośrodku został ustawiony tron królewski, na którym zasiadł Alfons V Wspaniałomyślny. Po obu stronach władcy przygotowane miejsca zajęli zarówno krewni monarchy, jak i członkowie jego dworu. Uroczystość rozpoczęły tańce ,a la usança de aquesta terra”, czyli miejscowe, tj. neapolitańskie. Po ich zakończeniu, jak relacjonował poseł, „fou feta en la dita sala, gran collació de confits de sucre a tothom generalment”. Ostatnim punktem uroczystości były tańce ,a la guisa nostrada" (Madurell Marimón, 1963: 311, n. 249).

Niewątpliwie na uwagę zasługuje fakt, że po raz kolejny w relacji poselskiej został użyty zwrot gran col·lació. Jak można sądzić, zastosowanie desygnatu gran miało bez wątpienia na celu podkreślenie uroczystego charakteru przyjęcia. Z drugiej strony mogło być wskazaniem typu przekąski ze słodyczami, w której istotną rolę odgrywały zarówno jakość i ilość oferowanych słodyczy, jak i zastosowana 
oprawa. Choć obie relacje są stosunkowo lakoniczne, autorzy wyraźnie zaznaczają elementy ceremonialne oraz oddają podniosły klimat obu wydarzeń. Co się tyczy drugiego opisu, możemy znaleźć analogię z zaprezentowanym powyżej przebiegiem uroczystego podjęcia przekąską ze słodyczy Joana de Clève podczas jego pobytu w Barcelonie 10 lat przed opisaną uroczystością na Zamku Kapuańskim w Neapolu. W czasie jednej i drugiej ceremonii konsumpcji słodyczy towarzyszyły tańce, z tym że podczas tej drugiej najpierw miały miejsce tańce miejscowe, a później katalońskie. Takie zestawienie miejscowych obyczajów z tymi wyniesionymi z ojczystej ziemi może być swoistym dowodem na przenikanie się różnych elementów kulturowych oraz wzbogacenie miejscowej obyczajowości o napływowe elementy.

Przytoczone przykłady wyraźnie dowodzą, że uroczysta przekąska ze słodyczy wraz z całą ceremonialną oprawą stała się nowym składnikiem neapolitańskiej kultury dworskiej. Z drugiej jednak strony wprowadzenie konsumpcji słodyczy w ramach autonomicznego posiłku i zastosowanie odpowiedniej oprawy stało się nowym elementem propagandy stosowanym przez Alfonsa V Wspaniałomyślnego po ostatecznym zdobyciu władzy w Królestwie Neapolu w 1442 roku. W tej perspektywie nie dziwi fakt, że zarówno słodycze, jak i uroczysta, ceremonialna forma ich konsumpcji odgrywały istotną rolę podczas wizyty w Neapolu Fryderyka III Habsburga (1452-1493). Sam fakt przyjazdu niemieckiego władcy do stolicy Królestwa Neapolu stwarzał dla Alfonsa V Wspaniałomyślnego doskonałą okazję nie tylko do utwierdzenia przyszłych sojuszów politycznych, lecz także do ostentacji bogactwa gospodarza.

Jak można sądzić, władca Korony Aragonii, a zarazem król Neapolu, w pełni wykorzystał nadarzającą się okazję. Świadectwo tego znajdujemy w licznych przekazach źródłowych, które wyszły spod piór humanistów związanych z neapolitańskim dworem. Z naszego punktu widzenia na szczególną uwagę zasługują dwie relacje odnoszące się do wzmiankowanego powyżej zagadnienia.

Pierwsza $\mathrm{z}$ nich to przekaz zawarty w katalońskojęzycznym przekładzie dzieła Antonia Beccadellego, zwanego Panoramitą (13941471), pt. Dictis et factis Alfonsi regis. Autorem wspomnianego 
przekładu jest Jordi de Centelles, który swoje tłumaczenie opatrzył tytułem Dels fets e dits del gran rey Alfonso i miejscami uzupełnił o zdania własnego autorstwa. Choć oba przekazy wyraźnie wskazują, że wizycie cesarza Fryderyka III w Neapolu towarzyszył podniosły nastrój, to relacja Centellesa wydaje się bardziej konkretna, lecz niepozbawiona panegirycznej otoczki. Jak zaznacza kataloński autor, jedną z rozrywek, jakie zapewniono Fryderykowi III, było uroczyste polowanie, które władca Neapolu zorganizował dla cesarza i jego orszaku. Aktywność łowiecka została połączona z uczestnictwem w wystawnych przyjęciach. O skali tych ostatnich miał świadczyć fakt, że zgodnie z przekazem autora - do stołu zasiadło sześć tysięcy ludzi, którzy spożywali rozmaite rodzaje mięs, w tym ptactwo łowne oraz znaczne ilości wina. Dopiero pod koniec swojego przekazu Jordi de Centelles zaznacza, że ,przekąska z rozmaitych słodyczy pokrywała ziemię" („la col·latió de diversos confits cobria la terra", Beccadelli, 1990: tekst łaciński: 256, 258, tekst kataloński: 257, 259).

Z kolei inny wybitny humanista, Vespasiano da Bisticci (14221498), w swojej pracy poświęconej 103 osobom żyjącym w XV stuleciu (wyd. 1859, pt. Vite di uomini illustri di XV secolo) zwrócił uwagę zarówno na wydatki związane z przyjęciem orszaku gości, wspomniane polowanie, jak i na kwestie odnoszące się do biesiadowania. Florencki humanista pisał:

Fevvisi uno desinare, che nella principale città d'Italia non si sarebbe potuto fare: in ogni luogo dove si mangiava, ch'erano infiniti luoghi, si mangiava in ariento; le vivande isplendidissime; confetti, non solo n'aveva chi ne voleva, ma egli si gittavano via, d'ogni ispecie che si possono pensare [podkreślenie moje - RH]. Eranvi più fontane per quella campagna ordinate, che gittavano chi greco, chi moscatello e chi vermiglio d'ogni ragione e tutti vini solenni; ed erano a ogni fonte tazze d'ariento, e uomini vi stavano, e andavanvi a bere chi voleva; quegli tedeschi se ne fornivano come si debbe (Vespasiano da Bisticci, 1859: 66-67).

Jak zaznaczono w cytowanym powyżej tekście, autor przekazu wyraźnie zaznaczył, że ilość i różnorodność słodyczy stały się kolejnym 
instrumentem, przy pomocy którego król Neapolu, nie licząc się z kosztami, zaprezentował cesarzowi swoje bogactwo.

Z naszego punktu widzenia na uwagę zasługują jeszcze inne źródła. Pierwsze $\mathrm{z}$ nich to anonimowy opis wizyty Fryderyka III w Neapolu, pt. Come lo Imperatore Federico entrò a Napoli e poi lo 4 di entrò l'Imperatrice in Aversa. Opis jest niezwykle szczegółowy. Autor niemal w reporterski sposób zrelacjonował pobyt cesarza w Neapolu i opisał precyzyjnie kolejne atrakcje, jakie dla cesarza i członków jego orszaku przygotował król Neapolu. Zupełnie pominął jednak opis uczt. Wspomniał jedynie, że konie cesarskie biorące udział w turniejach i wyścigach zamiast paszy otrzymały cukierki kolendrowe i słodycze cukrowe, co - jak można wnioskować - stanowiło rodzaj nagrody za wysiłek tych zwierząt w turniejach i wyścigach. (,a li cavalli dell'Imperatore, o della Imperatrice, e Re con sua compagnia, fu data biava di coriandoli e confetti di zuccaro", Anonim, 1908b: 487).

Z kolei w jednym z listów do króla Alfonsa V Afrykańczyka (14491481) datowanym na 18 kwietnia 1452 roku portugalski poseł pisał:

Senhor, da hi dous dias, ou tres, determinou o Emperador de fazer copula carnal de matrimonio com vossa Irmaa. Este dia, acabadas as justas, foram cear, e acabada a cea, vieram todos por vossa Irmaa, e levaraõ-na a casa do Emperador, e dansaram em sua salla quasi huma hora, e veyo collaçaõ maior, que a de Fernaõ Serveira, que com tres patos dizia que se fartaria muy bem, e lançarsehia na cama, o Emperador partiose da dança, antes da colaçaõ, e foise a sua camara, e acabada a dita colaçaõ, levou El Rey a ditta Senhora áquella mesma camara com poucos, salvo mulheres, e acharaõ-no jâ lançado, vestido entre os lenções, e tomaraõ vossa Irmaa, e lançaraõ-na na cama com elle tambem vestida, e cobriraõ-lhe as cabeças, e beijaraõ-se, e feito isto, levantaraõ-se e tornou-se a ditta Senhora â sua camara, e ficou o ditto Senhor na sua, e isto foy assim feito â uzança da Alemanha, porque assy foy acordado com El Rey de se fazer (Sousa, 1739: 642-643).

W świetle informacji zawartych w powyższej relacji możemy stwierdzić, że poseł portugalski relacjonował swojemu władcy szczegóły nocy poślubnej królewskiej siostry i szwagra. Co się tyczy spraw, 
które bezpośrednio nas interesują, to należy podkreślić, że gdy cesarz skończył wymierzać sprawiedliwość, najpierw zorganizowano ucztę, a później tańce, które trwały pół godziny. Po ich zakończeniu miała miejsce collaçaõ maior. Wydaje się, że autor relacji użył tego określenia w odniesieniu do wystawnego poczęstunku, podczas którego serwowano słodycze. $Z$ danych zawartych w powyższej relacji wynika, że cesarz nie uczestniczył w tańcach ani we wspomnianym poczęstunku, brali w nim udział tylko król Neapolu i cesarzowa Leonora. Ta ostatnia została odprowadzona do komnaty, w której przebywał cesarz oczekujący na moment konsumpcji świeżo zawartego małżeństwa.

Analiza powyższych przykładów uprawdopodobnia tezę, że faktycznym propagatorem idei ceremonialnych przekąsek ze słodyczy był Alfons V Wspaniałomyślny, a nie jego wnuk, Alfons II, jak twierdzili Claudio Benporat i Enrico Carnevale Schianca (Benporat, 2007; Carnevale Schianca, 2011: 168). Jak można sądzić, ten błędny pogląd zrodził się z nieuważnego odczytania fragmentu traktatu De convivencia, autorstwa Giovanniego Pontana (1426-1503), wybitnego humanisty i myśliciela związanego z dworem neapolitańskim (Pontano, 1518: 14; Benporat, 1999: 15-16; 2001: 93-99; 2001a: 10-16; 2007: 45-58). Informacje dotyczące słodkiej przekąski znajdują się w końcowej części dzieła, w rozdziale VI De secunda mensa (Pontano, 1999: tekst łaciński: 262, 264, tekst włoski: 263,265) i rozdziale VII De convitis honoris gratia susceptis (Pontano, 1999: tekst łaciński: 262, 264, tekst włoski: 263, 265).

Analiza zawartych tam informacji pozwala na nową interpretację danych odnoszących się do słodkich przekąsek. Otóż w rozdziale VI swojej pracy Pontano, wymieniając Alfonsa jako tego, który wprowadził (w domyśle: dawniej) zwyczaj wystawnych przekąsek, które dziś nazywany colazione (,in comessatiunculis, quas hodie collationes vocant”), wskazuje na Alfonsa V Wspaniałomyślnego, a nie jak dotychczas sądzono Alfonsa II, zmarłego tuż przed powstaniem dzieła. Po wtóre, można sądzić, że autor odwołał się do powszechnej pamięci o entuzjazmie wspomnianego władcy do tego typu przedsięwzięć: „eiusque rei initium coepit ab Alfonso cuius in hac, ut in ceteris splendoris partibus, magnum studium fuisse cognovimus" (Pontano, 1999: 
tekst łaciński: 262, 264, tekst włoski: 263, 265). W podobnym duchu można zinterpretować drugi z wymienionych fragmentów, na co zresztą jednoznacznie wskazał współczesny wydawca oryginału łacińskiego i przekładu na język włoski - Francesco Tateo (Pontano, 1999: 271).

$* * *$

Podsumowując niniejsze rozważania, można sformułować wnioski, które zostały ujęte w poniższych punktach.

Po pierwsze, zwyczaj słodkiej przekąski, który rozwinął się w kręgach klasztornych, prawdopodobnie na przełomie XIII i XIV wieku przeniknął do świata ludzi świeckich. W tym kręgu bardzo szybko uzyskał uznanie i cieszył się sporą popularnością. Choć pierwotnie przekąska były nazywana mianem collatio, to w źródłach pisanych nie zawsze występowała pod tą nazwą. Wydaje się, że wzmianki o spożywaniu słodyczy i wina są niczym innym jak właśnie wspominaną, choć niewymienioną z nazwy przekąską.

Po wtóre, wzmiankowana przekąska była pierwotnie praktykowana na gruncie prywatnym, a z czasem stała się elementem uroczystości o charakterze publicznym. Jak można sądzić, niniejszy transfer dokonał się chronologicznie najwcześniej na terenach Korony Aragonii w drugiej połowie XIV wieku i miał miejsce w środowisku mieszczańskim Barcelony. Zachowane przekazy źródłowe potwierdzają, że zwyczaj przekąski uzyskał oprawę ceremonialną i był praktykowany podczas wizyt oficjalnych gości - arystokratów, dostojników świeckich i duchownych czy też koronowanych głów bądź członków ich rodzin. Co najmniej do przełomu lat 30. i 40. XV wieku nieodłącznym elementem celebracji wspomnianej przekąski stał się odgórnie ustalony rytuał, którego stałym elementem były tańce. Tym samym słodka przekąska uzyskała wymiar reprezentacyjny i stała się instrumentem ostentacji bogactwa, a same słodycze - istotnym narzędziem propagandowym.

Po trzecie, ostentacyjny i reprezentacyjny wymiar słodkiej przekąski został przejęty przez kręgi dworskie władców Korony Aragonii. Choć kwestia ta wymaga dalszych badań źródłowych, wydaje się, że proces ten dokonał się najpóźniej we wczesnym okresie rządów 
Alfonsa V Wspaniałomyślnego, który zasiadł na aragońskim tronie w 1416 roku.

Po czwarte, zaangażowanie wspomnianego władcy w walkę o panowanie w Królestwie Neapolu w latach 20. i 30. XV stulecia stało się okazją do przeszczepienia na grunt włoski słodkiej przekąski w formie i kształcie wyniesionym z ojczyzny. Choć ten rodzaj posiłku był już znany w państwach włoskich, to przed czasami Alfonsa V Wspaniałomyślnego nie stał się programowym instrumentem ostentacji bogactwa. Działania wspomnianego monarchy pozwoliły więc nadać mu nowy wymiar, co sprawiło, że wystawna przekąska wpisała się w rytuał ostentacji uroczystości renesansowych na dworach władców włoskich schyłku XV wieku i stuleci następnych.

Po piąte, w świetle powyższych faktów konieczne jest odrzucenie dotychczasowego poglądu, że zwyczaj ceremonialnej przekąski upowszechnił się na ziemiach włoskich w latach 70. XV wieku. Zachowane świadectwa źródłowe stanowią mocną podstawę do stwierdzenia, że proces ten dokonał się już w latach 40. wspomnianego stulecia dzięki wieloletnim działaniom Alfonsa V Wspaniałomyślnego związanym ze zdobyciem tronu neapolitańskiego i umocnieniem panowania w Królestwie Neapolu po 1442 roku.

Po szóste, praktykowany przez Alfonsa V Wspaniałomyślnego zwyczaj wystawnej słodkiej przekąski stał się jednym z kilku instrumentów propagandowych, wykorzystywanych przez monarchę zarówno w polityce wewnętrznej, jak i na forum kontaktów z innymi władcami. Słodycze uchodziły za wyrób luksusowy, a ich spożywanie w różnych formach i kształtach stwarzało okazję do wywierania silnego wrażenia na konsumentach. W takim właśnie kształcie zwyczaj propagandowej przekąski na trwałe wpisał się do tradycji pełnego renesansu włoskiego i stał się jednym z elementów oddziaływania włoskiej kultury renesansowej w Europie przełomu XV i XVI wieku. 


\section{Bibliografia}

ADROER i TASSIS, A. (1995), „Un convit reial a la Barcelona del s. XV” w: Actes del I Col-loqui d'Història de l'Alimentació a la Corona d'Aragó. Edat Mitjana, t. II, Institut d'Estudis Ilerdencs, Lleida, s. 633-639.

ANONIM (D.) (1908a), „Come lo Re Alfonso d'Aragona entrò alla città di Napoli col carro triomfale" w: Racconti di storia napoletana, Archivio Storico per le provincie napoletane, 33, fasc. 3, Napoli, s. 478-480.

ANONIM (D.) (1908b), „Come lo Imperatore Federico entrò in Napoli, e poi lo 4 dì entrò l'Imperartrice in Aversa" w: Racconti di storia napoletana, Archivio Storico per le provincie napoletane, 33 (1908), fasc. 3, Napoli, s. 481-490.

BECCADELLI, A. (1990), Dels fets e dits del gran rey Alfonso, Editorial Barcino, Barcelona.

BÉNÉZET, J.-P. (1999), Pharmacie et médicament en Méditéranée occidentale (XIII-XVI siècles), Honoré Champion, Paris.

BENPORAT, C. (1999), „Convivialità, cucina e decori delle tavole nella Firenze del'400", Appunti di gastronomia, 28, Milano, pp. 5-21.

BENPORAT, C. (2001), Feste e banchetti. Convivialità italiana fra Tre e Quattrocento, Leo S. Olschki Editore, Firenze.

BENPORAT, C. (2001a), „De conviventia, un trattato di etica conviviale di Giovanni Pontano", Appunti di gastronomia, 36, Milano, s. 10-26.

BENPORAT, C. (2005), „Note per la storia dei confetti”, Appunti di gastronomia, 47, Milano, pp. 71-89.

BENPORAT, C. (2007), „La ,,collatione« una nuova forma conviviale”, Appunti di gastronomia, 52, Milano, s. 45-58.

BISTICCI, V. da (1859), Vite di uomini illustri del secolo XV, Barbèra, Bianchi e comp, Firenze.

BOCCACCIO, G. (1975), Dekameron, thum. E. Boyé, Państwowy Instytut Wydawniczy, Warszawa.

BRUNIQUER, E. G. (1912), Ceremonial dels magnifichs consellers y regiment de la ciutat de Barcelona. Rúbriques de Brunique, red. F. Carreras y Candi, B. Gunyalons y Bou, t. I, Impr. d'Henrich, Barcelona. 
BRUNIQUER, E. G. (1913), Ceremonial dels magnifichs consellers y regiment de la ciutat de Barcelona: Rúbriques de Brunique, red. F. Carreras y Candi, B. Gunyalons y Bou, t. II, Impr. d'Henrich, Barcelona.

CARNEVALE SCHIANCA, E. (2011), La cucina medievale. Lessico, storia, preparazioni, Leo S. Olschki Editore, Firenze.

CLARAMUNT, S. (1988), „Dos aspectes de l'alimentació medieval. Dels canonges a les «miserabiles personae»" w: Alimentació $i$ societat a la Catalunya medieval. Anuario de estudios medievales, Anex 20, Consejo Superior de Investigaciones Sientíficas, Barcelona, s. 167-172.

COMÈS, P. J. (1878), Libre de algunes coses asanyalades succehides en Barcelona y en altres parts format per Pere Joan Comes en 1583 y recóndit en lo Arxiu del Excelentíssim Ajuntament. J. Puiggari (red.), La Renaixensa, Barcelona, s. 94-102.

CORAZZA, B. del (1894), „Diario fiorentino di Bartolomeo di Michele del Corazza: anni 1405-1438", Archivio storico italiano, serie V, t. XIV, disp. 4, Firenze, s. 233-298.

COULON, D. (2004), Barcelone et le grand commerce d'Orient au Moyen Âge. Un siècle de relations avec l'Égipte et Syrie-Palestine (ca. 1330-ca. 1430), Casa de Velázquez, Madrid-Barcelone.

DURAN I SANPERE, A., Sanabre, J. (red.) (1930), Llibre de les solemnitats de Barcelona. Edició completa del manuscrit de l'Arxiu Històric de la Ciutati, t. 1: 1424-1546, Institució Patxot, Barcelona.

FACCIO, B. (1590), I fatti d'Alfonso d'Aragona primo re di Napoli, Apresso Giovanni et Gio. Paolo Giolitti de Ferrari, Vinegia.

GAJDA, Z. (2011), Do historii medycyny wprowadzenie, Wydawnictwo WAM, Kraków.

GUAL CAMARENA, M. (1965), Vocabulario del comercio medieval. Colección de aranceles aduaneros de la Corona de Aragón (siglos XIII y XIV), Excelentísima Diputación Provincial, Tarragona.

GIRONA I LLAGOSTERA, D. (1913-1914), „Itinerari del rey En Martí I”, Anuari, Institut d'Estudis Catalans, 5/1, Barcelona, s. 515-656.

GONZÁLEZ HURTEBISE, E. (1907), „Inventario de los bienes muebles de Alfonso V de Aragón como infante y como rey (1412-1424)", Anuari. Institut d'Estudis Catalans, 1, Barcelona, s. 148-188. 
HRYSZKO, R. (2013), „Media aeva dulcia«. Analiza produkcji i konsumpcji w Koronie Aragonii w XIV i XV w., Towarzystwo Wydawnicze Historia „Iagellonica”, Kraków.

HRYSZKO, R. (2019), „The Sweet War, or How Military Campaigns of Alfonso V of Aragon Affected the Eating Habits in Early to Mid-15th Century", Perspektywy kultury, 26 (3/2019), Biblia w kulturze, Kraków, s. $135-159$.

HRYSZKO, R., SASOR, R. (2017), Średniowieczne słodycze katalońskie w źródlach i literaturze ( $z$ wyborem tekstów z XIV i XV wieku), Towarzystwo Wydawnicze Historia Iagellonica, Kraków.

KUHNE, R. (1994), „El azúcar. Usos dietéticos y farmacéuticos según los médicos árabes medievales" w: 1492: lo dulce en la conquista de Europa. Actas del quarto seminario internacional sobre la caña de azúcar, Motril 21-25 septembre 1992, Diputación General de Granada, Granada, s. 41-62.

KUHNE BRABANT, R. (1997). „Le sucre et le doux dans l'alimentation d'al-Andalus", Médiévales, 33, automne, Vincennes, s. 55-67.

MARANGES, I. (1998), Dolços medievals per avui, Edicion El Médol, Tarragona.

MARÍN, M. (2000), „El sucre a la gastronomia andalusina a partir de la Fadāla de Ibn Razīn” w: Sucre \& Borja. La canyamel dels ducs. Del trapig a la taula, edició a cura de J. A. Gisbert. Generalitat Valenciana, Gandia, s. 52-57.

MADURELL MARIMÓN, J.M. (red.) (1963), Mensajeros barceloneses en la corte de Nápoles de Alfonso V de Aragón, Consejo Superior de Investigaciones Sientíficas, Barcelona.

MAINERI, M. de, (1506), Regimen sanitatis Magini mediolanensis cum nonnulis insuper Auicenne ac plerumq[ue] aliorum auctoru[m] margine cartharum insertis; Insuper opusculum de fleubothomia editu[m] a Reginaldo de Villa noua, per Gaspardum Philips, expensis Iohannis Petit, Jehan Petit, Parisium.

NEWBIGIN, N. (2011), „The Florentine Celebrations of 1459”, Letteratura italiana antica, 12, Pisa-Roma, s. 17-135.

OUERFELLI, M. (2008), Le sucre. Production, commercialisation et usage dans Méditerranée médiévale, Brill, Leiden-Boston. 
PLOUVIER, L. (1999), „L'introduction du sucre en pharmacie”, Revue d'histoire de la pharmacie, 87 (332), Paris, s. 199-216.

PONTANO, G. G. [Ioannis Ioviani Pontani] (1518), Opera omnia soluta oratione composita, t. I, In aedibus Aldi et Andreae Soceri, Venetiis.

PONTANO, G. G. (1999), I libri delle virtu sociali, a cura di F. Tateo, Bulzoni Editore, Roma.

RIERA-MELIS, A. (2002), „Il Mediterraneo. crogiuolo di tradizioni alimentari. Il lascito islamico alla cucina catalana medievale" w: Il mondo in cucina. Storia, identità, scambi a cura di M. Montanari, 3-43, Laterza, Bari-Roma.

SAVAGE-SMITH, E. (2005), „Medycyna” w: Historia nauki arabskiej, red. R. Rashed, t. 3: Technika, alchemia, nauki przyrodnicze i medycyna, Wydawnictwo Akademickie Dialog, Warszawa, s. 161-221.

SOUSA, A.C. de (1739), Provas da Historia genealogica da casa real portugueza.Tirados dos instrumentos dos archivos da Torre do Tombo, da serenissima casa de Bragança, de diversas cathedraes, mosteiros, e outros particulares deste reyno, t. I, Lisboa Occidental: Na officina Sylviana da Academia Real, Lisboa.

SUÑE ARBUSSÁ, J. M., Sorní Esteva, X., (1983), „La farmacia en Barcelona desde Jaume I a Jaume II (1213-1327)", Boletín de la Sociedad Española de Historia de la Farmacia, 34, nr 135, Madrid, s. 59-103.

SUÑE ARBUSSÁ, J. M., Sorní Esteva, X., (1985), „La farmacia en Barcelona desde Alfonons el Benigne a Pere el Ceiemoniós (1327-1381)", Boletín de la Sociedad Española de Historia de la Farmacia, 36, nr 141-142, Madrid, s. 67-79.

VELA I AULESA, C. (1996), „La col-lació, un àpat medieval poc conegut” $\mathrm{w}$ : La Mediterrània àrea de convergència de sistemes alimentaris (segles V-XVIII). XIV Jornades d'Estudis Històrics Locals: realizades a Palma del 29 de novembre al 2 dicembre de 1995), Consejo Superior de Investigaciones Sientíficas, Palma, s. 669-686.

VELA I AULESA, C. (2006), „Ordinacions. privilegis i oficis la regulació de l'art de l'especieria (s. XIV-XV)", Anuario de Estudios Medievales, 36/2, Barcelona, s. 839-882.

VIGNA, A. (1879), Codice diplomatico delle colonie tauro-liguri durante la signoria dell'Ufficio di San Giorgio (MCCCCLIII-MCCCCLXXV), t. II, 
Wkład Alfonsa V Wspaniałomyślnego...

parte II (anni 1473-1475). Atti della Società Ligure di Storia Patria, volume. VII, p. II, fascicolo. I-II, Genova.

VALSALOBRE, P. (2005), „Apotecaris i receptes en la literatura catalana antiga", Mot so razo, nr 4, 2005, Girona, s. 34-46. 